\section{of Dairy and}

Veterinary Science (CJDVS)

Volume 2 Issue 3, 2021

Article Information

Received date : November 23, 2021

Published date: December 27, 2021

*Corresponding author

Milva Pepi, Stazione Zoologica Anton

Dohrn, Fano Marine Centre, Viale

Adriatico 1-N, 61032 Fano, Italy

Keywords

: Cattle Livestocks; Antibiotic Resistance;

Mediterranean Area; One Health

Distributed under Creative Commons

CC-BY 4.0

\section{Antibiotic Resistance in Cattle Livestocks in the Mediterranean Area With A One Health View}

\author{
Milva Pepi ${ }^{{ }^{*}}$ and Silvano Focardi ${ }^{2}$ \\ ${ }^{1}$ Stazione Zoologica Anton Dohrn, Fano Marine Centre, Viale Adriatico 1-N, 61032 Fano, Italy \\ ${ }^{2}$ Department of Environmental Sciences, Università di Siena, Via Mattioli, 4, 53100 Siena, Italy
}

\section{Abstract}

Antibiotics are used in livestocks not only in case of infections but also in prophylactic treatments to favour growth of animals. They are often added to feed, with a high percentage of unmodified antibiotics reaching intact the environment and constituting new emerging contaminants. Especially in the past, the same antibiotics supplied to animals could also be used in humans. Antibiotics resistance onset can originate inside the animals, in the resistome of the intestine, with a similar mechanism as the antibiotic resistance triggering in humans. Once activated within cattle, antibiotic resistant bacteria and related antibiotic resistance genes can be spread via food, milk and meat, or via manure which can be spread into the environment during fertilization procedures. Antibiotic resistant bacteria and genes of antibiotic resistance can thus reach human beings and the resistance genetic determinants can be included in pathogenic bacteria, vinifying action of antibiotics against those pathogens. The Mediterranean area presents a high density of dairy cattle livestocks and the problem of antibiotic resistance spread is of great concern. It is important to monitor the extent of antibiotic resistance diffusion and the possible consequent ineffectiveness of the known antibiotics against pathogenic bacteria. If from one hand it is of paramount importance to discover new antibiotics active against pathogenic bacteria, although this approach needs time, from the other hand it is mandatory to find new approaches facing with the problems of antibiotic resistance. A One Health approach, focusing on the cooperation of medical and veterinarian staffs, including people operating for environmental safeguard, could represent a valid method to actuate a decrease of the use of antibiotics in cattle livestocks and to operate with a continuous control and a monitoring of the critical points, in order to counteract the challenge of antibiotic resistance. This minireview was focused on antibiotic resistance onset in cattle livestocks in the Mediterranean area, calling attention on the high potential of spread of antibiotic resistance in humans, animals and in the environment, thus evidencing the need of a One Health approach to face with this concern.
Introduction

Antibiotics were discovered in the past century, with penicillin described in 1928 by Sir Alexander Fleming, resulting in a significant improvement in human health conditions. During the final phases of the Second World War, antibiotics began to be used in food animals, following accessibility to abundant productions of lyophilised preparations of penicillin, also made available for veterinarians [1]. The use of antibiotics in animals can be finalized to treatment of infectious disease, adopting metaphylaxis procedures, in which high doses of antibiotics are given for a short period with treatments extended to the whole flock to prevent the dissemination of illness in the flock, despite the exhibition of clinical symptoms in a few animals $[2,3]$. Concerning the antibiotics used to treat the most common diseases in cattle livestocks, which include bovine pneumonia, diarrhoea, and shipping fever, they can comprehend amoxicillin, penicillin, erythromycin, quinolones, gentamicin, novobiocin, tylosin, tilmicosin, and tetracycline [4]. In case of pneumonia, the first choice antibiotics are represented by oxytetracyclines and spectinomycin, the second choice are constituted by florfenicol and macrolides, and the last choice of antibiotics represented by second-, third-, and fourth-generation cephalosporins [5]. In presence of clinical mastitis it is recommended the application of narrow-spectrum antibiotics, with $\beta$-lactams as first-choice antibiotics when mastitis originated from streptococci, and penicillin when the aetiological agents are staphylococci [5,6]. Antibiotics can be administered to the whole herd with the aim of preventing infectious mastitis, intramammary and during periods of nonbreastfeeding [7].

In the mean time, antibiotics can be added to feed not only to treat infections, but to prevent the development of diseases and to promote growth of animals, through the procedure called prophylaxis. In this case the administration of antimicrobials in the feed or the drinking water occurs in low, sub therapeutic, doses for a longer period of time, usually for several weeks. Overall, the use of antibiotics in animals can overcome that in human beings [8]. Throughout the years, the use of antibiotics for nontherapeutic purposes in food animals has been more frequent than for therapeutic applications. It is estimated that in most developed nations, livestock alone use $50-80 \%$ of antibiotics produced [9]. The administered sub therapeutic doses of antibiotic are not sufficient to destroy the target bacteria, but can allow the more resistant of them to survive. Antibiotic resistance can be triggered when an administered dose of antibiotic provides an opportunity for bacteria to develop resistance [10]. In this minireview, a description of the use of antibiotics in cattle livestock is presented, focusing on onset of antibiotic resistances and on their spread via different mechanisms. A description of antibiotic resistance in cattle livestock of the Mediterranean area, and possible views with a One Health approach, are reported.

\section{Antibiotic Resistance in Cattle Livestocks}

The overuse or misuse of antibiotics caused selection of resistant bacteria, according to the World Health Organization, the antibiotic resistance was defined as follows: "Antimicrobial resistance... is resistance of a microorganism to an antimicrobial drug that was originally effective for treatment of infections caused by it.” [11]. The onset of antibioticresistant bacteria can occur soon after their first contact. It was known that Staphylococcus aureus strains isolated in 1948, 
evidenced resistance to penicillin, and in the same year, soon after the antibiotic use, resistance to streptomycin was observed in Mycobacterium tuberculosis isolates. Few years later, in the 1950s, antibiotic resistance was detected in other pathogenic bacteria, such as Escherichia coli, Shigella spp. and Salmonella enterica, and in the 1960s, in Enterobacteriaceae, antibiotic-resistant bacteria such as Extended Spectrum $\beta$-Lactamases (ESBLs), Vancomycin-Resistant Enterococcus spp. (VRE), MethicillinResistant Staphylococcus aureus (MRSA), and multidrug-resistant Acinetobacter baumannii were highlighted. Concerning outbreaks resulting from resistant bacteria originated from animals, this is of very high concern [7].

Bacteria can be resistant to one or to several different antibiotics, as multidrug resistant bacteria. Resistance to antibiotics can be developed through the multiplication of bacteria developing a natural mutation conferring resistance to the antibiotic, or can be developed by the horizontal resistance genes transfer between bacteria. Horizontal transmission of resistance genes represents a major cause of increasing antibiotic resistance. It can occur in different ways: i) through natural processes of gene transfer inside cells, via a mechanism called transformation; ii) via mobile segment of DNA known as transposons and plasmids, in the conjugation mechanism; iii) by transferiment of DNA via bacteriophages in the process of transduction $[12,13]$. Genes for antibiotic resistance in bacteria isolated from patients suffering of Escherichia coli urinary tract infections and Salmonella infections were recovered also in bacteria isolated from animals, probably due to gene transfer. Food-producing animals represents a major reservoir for mobile genetic elements, as integrons, carrying antimicrobial drug-resistant genes. They may also serve as a source for the transfer of these genes not only to Escherichia coli and Salmonella but also to other members of Enterobacteriaceae family and other bacterial species $[3,14]$.

The use of antibiotics in cattle livestocks has the potential to stimulate the development and dissemination of antibiotic resistant genes among different types of enteric bacteria characteristic for ruminants, as well as potentially pathogenic species related to the focal microbiome. Some of these bacteria may be pathogenic to humans, and hence could pose a threat to human health if they additionally acquire resistances. Moreover, non-pathogenic bacteria from manure might transfer antibiotic resistan genes to pathogens existing in manure, soil, or food consumed by animals or humans $[15,16]$. Furthermore, manure from dairy cows, commonly used as a soil fertilizer, may harbour diverse new variants of antibiotic resistant genes from the gut microbiota of cattle [17].

\section{Genes of Antibiotic Resistance}

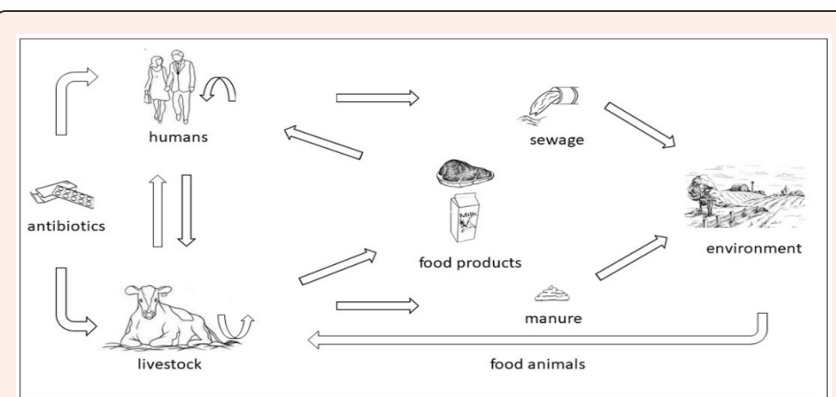

Figure 1: Different contexts of antibiotic use related to livestock farms and modalities of contact and possible transfer of antibiotic resistance (see text for explanations).

The most widely-used antibiotics in cattle production systems are tetracyclines, being used to treat skin, respiratory and gastrointestinal tract diseases. Furthermore, tetracycline resistance may develop rapidly because tetracycline antibiotic resistan genes are often located on mobile genetic elements [18]. The presence of five classes of tetracycline resistance genes in bovine focal samples was showed along with two classes of sulfonamide resistance genes and five classes of erythromycin resistance genes. These features may suggest that treatment with this antibiotic may enhance antibiotic resistance genes transfer. An increase in the number of Escherichia coli isolates carrying blaCMY-2 was observed, probably originated from a higher frequency of plasmidmediated antibiotic resistant genes transfer by horizontal genes transfer to other enteric bacteria, including potential zoonotic pathogens [19]. A strain carbapenemaseproducing Acinetobacter spp. harbouring the blaOXA-23 carbapenemase gene have been isolated from dairy cattle faces, along with Acinetobacter baumannii with the blaOXA-497 gene [8]. Klebsiella pneumoniae harbouring the blaNDM-5 gene was also isolated from samples of faces from dairy cows with mastitis from Jiangsu Province, China, and in all isolates, the blaNDM-5 gene was found [20]. From dairy cows, including one co-producing the transferrable colistin resistance gene $\mathrm{mcr}-1$ and another co-harbouring the carbapenemase gene blaVIM-2 were isolated [8]. In enterococci isolated from French cattle, intrinsic van $C$-mediated and acquired vanAmediated vancomycin resistance was reported [21]. These examples indicate that the genetic information of antibiotic resistance diffused from cattle livestocks can reach different compartments and can extend to human pathogens, thus representing a real threat for human health. A possible scheme of interactions among different contexts related to cattle livestocks and how these compartments interact among themselves, functioning as ways of communications and possible exchanges for antibiotic resistant bacteria and related genes of resistance, is reported in Figure 1.

\section{Spread of Antibiotic Resistance from Cattle Livestocks}

The antibiotic resistome evidences the pool of genes codifying for an antibiotic resistance phenotype with bacterial populations able to transfer antibiotic resistance genes by horizontal transfer to other microbial ecosystems. Both human and animal resistome comprehend strains spreading genes of antibiotic resistance, as result of intensive antibiotics use and bacterial genetic transfer [22]. In the case of the Livestock-Associated Meticillin Resistant Staphylococcus aureus (LA-MRSA) in dairy cattle, the first probable case of MRSA transmission between humans and cows were reported. Five isolates of MRSA were cultured from the samples collected from cows with asymptomatic mastitis. In the same time, nasal swabs were collected from different people, having contacts: the dairyman, veterinarian and some of their family members. The dairyman, the veterinarian and several members of the veterinarian's family tested positive for MRSA. DNA sequencing was performed on all of the MRSA isolates revealing to have identical antibiotic sensitivity profile and were of the same clonal lineage type. This study confirmed the transmission of MRSA between cattle's and the farm workers and between people in a family environment, confirming the risk of intra- and interspecies transmission of LA-MRSA [23]. A way of transmission of resistant bacteria and resistance genes from food animals to people is represented by food products of animal origin. In fact, they can be often contaminated with bacteria, and thus likely constituting the main route of transmission. Direct contact with animals or the animal environment, however, may also be of significance, depending on the type of bacteria. Such foods as fruits and vegetables contaminated by animal waste or contaminated water may also constitute a transmission route. Thus, antibiotic resistance is a food safety challenge. Mastitis is an inflammation of the mammary gland causing decreased milk production and quality, decreased cheese yield, increased cost of treatment, labour and culling and is mainly caused by bacteria of the species Staphylococcus aureus. Mastitis is also caused by many other bacteria such us Streptococcus spp., Escherichia coli, Pseudomonas spp., and Mycoplasma spp. Currently, the use of antibiotics is the most common treatment and $\beta$-lactams are the most frequently classes used for the treatment of mastitis. Resistance to antibiotics may be acquired and resistant bacteria may contaminate food products and they could be transmitted to humans through the food chain [24].

Bacterial antibiotic resistance can originate from antibiotic residues present in wastewater from animal production farms. These antibiotics residues can persist in soil and in aquatic environments. Transfer of antibiotic resistance occurs via spread of bacterial resistant strains or, indirectly, by horizontal gene transfer to other commensal or pathogenic bacteria, and commensal bacteria of the gastrointestinal tract, as Enterococcus spp., important carriers of antibiotics resistance expansion [25]. An agricultural land in the Azores archipelago, where pasture for dairy and beef cattle breeding was the main land use, was characterized for the antibiotic resistance profile of enterococci isolated from soils, evidencing many Vancomycin-Resistant (VRE) strains, often associated with penicillin and aminoglycoside resistance, and which present serious difficulties in therapeutic treatment. Among them, a VRE strain of Enterococcus faecalis was characterized, harbouring the vanA, the aph $3^{\prime}$ and aac6'-Ie-aph(2')-Ia antibiotic resistance genes, [25]. The environment represents a potential reservoir of antibiotics as well as antibiotic-resistant pathogens, which can then enter the food chain, leading to the selection of an antibiotic-resistant microbiota [26]. A tetracycline-resistant Escherichia coli strain and its tet A gene were tested for the capacity to survive in manure compost and the incidence of oxytetracyclineresistant bacteria and the persistence of the tet $A$ gene in cow farms was examined. Both oxytetracycline-resistant Escherichia coli and the resistance tetA gene persisted for many days in cow manure compost. High concentrations of antibiotic resistance genes and the presence of antibiotic-resistant bacteria may pose a risk to public health because these bacteria and genes could be transferred to natural soil microorganisms and then enter the human chain [27]. Livestock farms are important pollution sources 
of antibiotic resistant genes and antibiotic resistant bacteria that can be spread in the air of the surrounding environments due to intensive use of antibiotics in the livestock context. Bioaerosol has been found to be an important spread route of antibiotic resistant genes. Many studies have confirmed the association of antibiotic resistance between farm animals and farmers. The genus Staphylococcus is well known for the potential zoonotic pathogenic species and frequently colonize the skin and upper respiratory tracts of human and animals, among which Staphylococcus aureus is considered to be an important zoonotic pathogen [28,29]. Spread of airborne antibiotic resistant Staphylococcus spp. could pose a significant risk to human health and dissemination of livestock farms Staphylococcus spp. via aerosol emission to the adjacent environment represents an important concern [30]

Antibiotic Resistance from Cattle Livestocks in the Mediterranean Basin

The Mediterranean region is a cultural melting pot built from very importan and developed civilizations. Even though the Mediterranean region reveals strong differences in terms of consumer behaviour or socio-cultural profiles, natural conditions or economic situations, main common issues relative to animal production can be pointed out. Concerning the domestication and stabilization of the animals in the history, the transition from foraging and hunting to farming and herding represents an important step. Since the use of animal meat began long after domestication, the initial motivation that would have prompted populations to domesticate ruminants may have been based on the use of the milk [31]. Following the domestication of livestock species, including cattle, and their subsequent dispersal throughout the Mediterranean Basin, it was evidenced that the location of colonist farming enclaves during the Neolithic expansion in the Mediterranean Basin dates 10,500-9,000 B.P. and document the arrival of early pioneers. It was hypothesized that the Neolithic expansion originated somewhere in the Northern Levant, near Cyprus, from which the pioneer colonists transported the economically important fauna, including livestock species as cattle [32]. Beef and veal production is concentrated in France, Italy and Spain. Turkey and Egypt also have a significant production. In the Mediterranean area, large spatial differences also characterize the livestock subsector, with meat production included in a range from 0,1 to $143.910^{4}$ tonnes in the period between 2014 and 2018 [33]. In the Mediterranean basin, during the period from 2014 to 2018, France, Turkey and Italy were detected as the main milk producers, with averages equal to $262.710^{5}, 197.210^{5}$ and $119.310^{5}$ tonnes, respectively [33].

Features in cattle livestocks of the Mediterranean countries concerning isolated antibiotic-resistant bacterial strains, genes of resistance and native sampling sites, were described in Table 1. Antibiotic resistant strains of the species Staphylococcus aureus were recovered in almost all tested cattle livestocks of Mediterranean countries, mostly isolated from raw milk in presence of mastitis, often with resistance to methicillin (MRSA), and the corresponding resistant genes $m e c A$ and $m e c C$ (Table 1).

Table 1: Antibiotic resistant bacteria and genetic determinants of resistance in dairy cattle in the Mediterranean area. MRSA=Methicillin Resistant Staphylococcus aureus; VRSA=Vancomycin Resistant Staphylococcus aureus; CoNS=Coagulase Negative Staphylococci; CoPS=Coagulase Positive Staphylococci; NAS=Non-Aureus Staphylococci; ESBLs=Extended Spectrum Beta-Lactamases.

\begin{tabular}{|c|c|c|c|c|c|}
\hline Countries & Isolated Resistant Bacteria & Antibiotics & $\begin{array}{c}\text { Antibiotic } \\
\text { Resistance Genes }\end{array}$ & Samples Origin & References \\
\hline Albania & Staphylococcus aureus & tetracycline, oxacillin, erythromycin, ampicillin & & raw milk & [34] \\
\hline & $\begin{array}{l}\text { Staphylococcus aureus, CoNS, } \\
\text { (isolated } 2 \text { MRSA and } 1 \\
\text { VRSA strains) }\end{array}$ & penicillin G, tetracycline, methicillin, vancomycin & & $\begin{array}{l}\text { raw milk in presence of } \\
\text { mastitis }\end{array}$ & [35] \\
\hline & $\begin{array}{l}\text { Staphylococcus aureus, } \\
\text { Escherichia coli }\end{array}$ & $\begin{array}{l}\text { penicillin, oxacillin, ampicillin, amoxicillin+clavulanic } \\
\text { acid }\end{array}$ & & raw milk & [36] \\
\hline & Escherichia coli & $\begin{array}{l}\text { amoxicillin, tetracycline, amoxicillin-clavulanic acid, } \\
\text { trimethoprim-sulfamethoxazole }\end{array}$ & tetA, blaTEM-1 & $\begin{array}{l}\text { raw milk in presence of } \\
\text { mastitis }\end{array}$ & [37] \\
\hline Algeria & $\begin{array}{l}\text { Staphylococcus aureus, } \\
\text { (isolated } 4 \text { MRSA strains) }\end{array}$ & penicillin $\mathrm{G}$, fusidic acid, tobramycin, methicillin & & raw milk & [38] \\
\hline $\begin{array}{l}\text { Bosnia- } \\
\text { Herzegovina }\end{array}$ & $\begin{array}{l}\text { Staphylococcus aureus, } \\
\text { Escherichia coli, } \\
\text { Enterobacteriaceae }\end{array}$ & penicillin G, bacitracin, trimethoprim/sulfamethoxazole & & $\begin{array}{l}\text { raw milk in presence of } \\
\text { mastitis }\end{array}$ & [39] \\
\hline Croatia & Staphylococcus aureus & penicillin and ampicillin & & dairy cattle mastitis & [40] \\
\hline \multirow[b]{3}{*}{ Egypt } & $\begin{array}{l}\text { Escherichia coli, } \\
\text { Staphylococcus aureus, } \\
\text { streptococci, NAS }\end{array}$ & $\begin{array}{l}\text { ampicillin, amoxicillin-clavulanic acid, cefoxitin, } \\
\text { levofloxacin, ciprofloxacin, doxycycline } \mathrm{HCl} \text {, gentamicin, } \\
\text { florophenicol, sulfamethoxazoletrimethoprim, }\end{array}$ & $\begin{array}{l}\text { mecA, blaZ, } \\
\text { aph(3')-IIIa, cfb, } \\
\text { tetA, sull, fimH, } \\
\quad \text { tsh }\end{array}$ & $\begin{array}{l}\text { raw milk in presence of } \\
\text { mastitis }\end{array}$ & [41] \\
\hline & $\begin{array}{c}\text { Streptococcus aureus, } \\
\text { Escherichia coli, Pseudomonas } \\
\text { aeruginosa, (isolated 5MRSA } \\
\text { strains) }\end{array}$ & $\begin{array}{l}\text { penicillin, oxacillin, streptomycin, ceftriaxone, } \\
\text { enrofloxacin, levofloxacin, methicillin }\end{array}$ & & $\begin{array}{l}\text { raw milk in presence of } \\
\text { mastitis }\end{array}$ & [42] \\
\hline & Escherichia coli (ESBL) & $3^{\text {rd }}$ generation cephalosporins & $\begin{array}{c}\text { blaCTX-M15, } \\
\text { blaCTX-M9, } \\
\text { blaTEM, blaSHV, } \\
\text { blaOXA-48, } \\
\text { blaOXA-181 }\end{array}$ & $\begin{array}{l}\text { rectal swabs, } \\
\text { environmental samples } \\
\text { from the stalls }\end{array}$ & [43] \\
\hline \multirow[b]{3}{*}{ France } & $\begin{array}{l}\text { Streptococcus uberis, } \\
\text { Escherichia coli, CoPS }\end{array}$ & $\begin{array}{l}\text { tetracycline, third-generation cephalosporin, amoxicillin, } \\
\text { tetracycline }\end{array}$ & & dairy cattle mastitis & [44] \\
\hline & $\begin{array}{c}\text { Streptococcus uberis, } \\
\text { Escherichia coli, CoPS, CoNS, } \\
\text { Streptococcus dysgalactiae }\end{array}$ & penicillin G, macrolides, tetracycline & & dairy cattle mastitis & [45] \\
\hline & $\begin{array}{l}\text { Staphylococcus aureus } \\
\text { (MRSA) }\end{array}$ & methicillin & mecA, mecC & $\begin{array}{l}\text { raw milk/nasal and } \\
\text { rectalswabs }\end{array}$ & [46] \\
\hline
\end{tabular}

Citation: : : Pepi M and Focardi S (2021) Antibiotic Resistance in Cattle Livestocks in the Mediterranean Area With A One Health View. Corpus J Vet Dairy Sci 2: 1029 


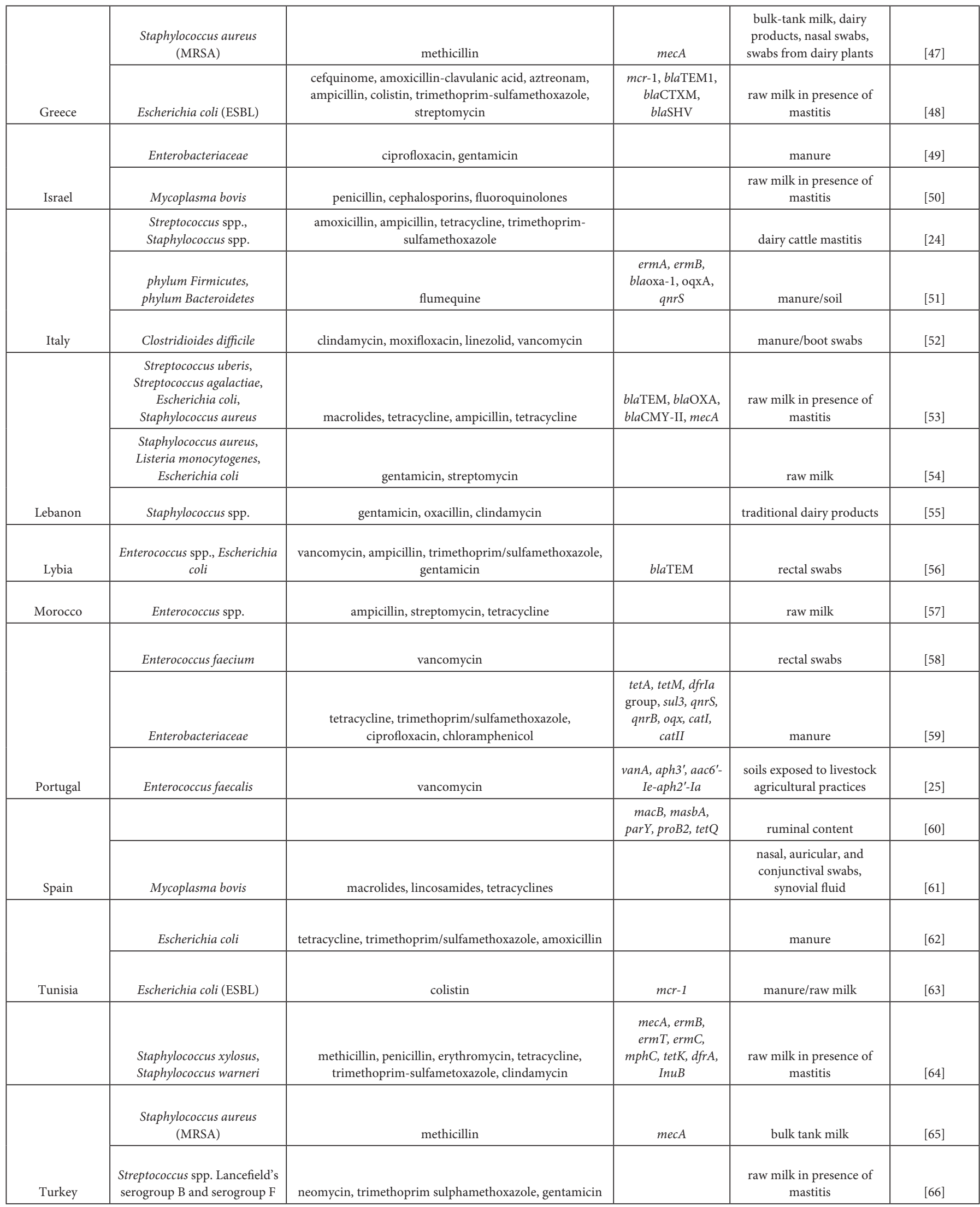

Citation: : : Pepi M and Focardi S (2021) Antibiotic Resistance in Cattle Livestocks in the Mediterranean Area With A One Health View. Corpus J Vet Dairy Sci 2: 1029 


\section{One Health Approach to the Concern of Antibiotic Resistance}

Health of people is connected to the health of animals and the environment and antibiotic resistance has clear links to each of these three domains. The contribution of livestock production to the global antibiotic resistance can create ideal conditions for bacteria to fix genes that confer resistance. These genes can subsequently be transmitted to human-adapted pathogens or to human gut microbiota via people, by mean of contaminated food or the environment. These compartments also provide ideal conditions for the amplification of genes that may have arisen in people or the environment. The fact that the antibiotics used in human and animal health largely comprise the same or very similar molecules, would be expected to drive the transmission of resistance between animals and people, either directly or via the environment. Multidrug-resistant strains as the common pathogens like Escherichia coli, Klebsiella pneumoniae and Staphylococcus aureus are of high concern and it thus emerge the need to consider the problem from a One Health point of view, including a strict collaboration among human health, animal health and environmental health The One Health approach is well defined concerning the great problem of antibiotic resistance originated from cattle livestock, and diffusing in human contexts and in environmental compartments.

The relative roles of these three aspects in the development, transmission and persistence of antibiotic resistant bacteria and genes is poorly investigated. A One Health approach to dealing with antibiotic resistance, embracing all three domains, would represent a powerful tool and could open the way to a new approach to solve problems, where collaboration and pursuing common interests are at the base of the project [67]. Veterinarians and livestock producers must adapt to accept decreasing the consumption of antibiotics by livestock and in reducing the occurrence of antibiotic resistance in bacteria that inhabit livestock, humans, and the environment, affirming the "One Health' approach as an efficacy attitude against antibiotic resistance diffusion, for the future [68].

\section{Conclusion}

In this minireview, the great concern of antibiotic resistance is considered in relation to the use of antibiotics in cattle livestocks. The strict relationships among animals, humans and environment allow the spread of antibiotic resistance triggered in cattle's to the humans and the environment by mean of food products, manure, direct contact, diffusion in air. The communications among these different sectors are very easy and continuous and characterized by different directions. Mediterranean basin is historically an important area for cattle livestocks and this activity could have important consequences as spread from animal and environmental sites to human pathogens of antibiotic resistant bacteria and related genes of antibiotic resistance. Considering that antibiotic resistance spreads between different compartments and that this can lead to the onset of multi-resistant pathogenic bacteria not sensitive to the available antibiotics, there is a strong need to tackle the problem from different points of view. A One Health intervention aimed at reducing the consumption of antibiotics in cattle farms, at manage the dispersion of manure in the environment and at increasing the controls of food products, would constitute an important system of protection against the serious threat of antibiotic resistance.

\section{References}

1. Ventola CL (2015) The antibiotic resistance crisis: Part 1: causes and threats Pharmacy and Therapeutics 40(4): 277-283.

2. Marshall BM, Levy SB (2011) Food animals and antimicrobials: impacts on human health. Clinical Microbiology Reviews 24(4): 718-733.

3. Compassion in World Farming (2011) Antibiotics in Farm Animal Production Public Health and Animal Welfare.

4. McEwen SA, Fedorka-Cray PJ (2002) Antimicrobial use and resistance in animals. Clinical Infectious Diseases 34(S3): S93-S106.

5. Constable P, Pyorala S, Smith GW (2008) Guidelines for antimicrobial use in cattle. In: Guardabassi L, Jensen LB, Kruse H (Eds.), Guide to antimicrobial use in animals. Ames (IA): Blackwell Publishing Ltd, US, pp. 1-222.

6. Wagner S, Erskine R (2013) Antimicrobial drug use in mastitis. In: Giguère $S$ Prescott JF, Dowling PM (Eds.), Antimicrobial therapy in veterinary medicine. (5th edn) Ames (IA): Blackwell Publishing, US, pp. 519-528.

7. Economou V, Gousia P (2015) Agriculture and food animals as a source of antimicrobial-resistant bacteria. Infection and Drug Resistance 8: 49-61.

8. Zalewska M, Błazejewska A, Czapko A, Popowska M (2021) Antibiotics and antibiotic resistance genes in animal manure - Consequences of its application in agriculture. Frontiers in Microbiology 12: 610656

9. Cully M (2014) Public health: The politics of antibiotics. Nature 509(7498) S16-S17.

10. Van TTH, Yidana Z, Smookera PM, Coloec PJ (2020) Antibiotic use in food animals worldwide, with a focus on Africa: Pluses and minuses. Journal of Global Antimicrobial Resistance 20: 170-177.

11. World Health Organization (2014) Antimicrobial Resistance.

12. Carattoli A (2003) Plasmid-mediated antimicrobial resistance in Salmonella enterica. Current Issues in Molecular Biology 5(4): 113-122.

13. Pepi M, Focardi S (2021) Antibiotic-resistant bacteria in aquaculture and climate change: A challenge for health in the mediterranean area. International Journal of Environmental Research and Public Health 18(11): 5723.

14. Ajiboye RM, Solberg OD, Lee BM, Raphael E, DebRoy C, et al. (2009) Global spread of mobile antimicrobial drug resistance determinants in human and animal Escherichia coli and Salmonella strains causing community-acquired infections. Clinical Infectious Diseases 49(3): 365-371.

15. Brichta-Harhay DM, Arthur TM, Bosilevac JM, Kalchayanand N, Shackelford SD, et al. (2011) Diversity of multidrug-resistant Salmonella enterica strains associated with cattle at harvest in the United States. Applied and Environmental Microbiology 77(5): 1783-1796.

16. Wang S, Yin B, Yu L, Dang M, Guo Z, et al. (2020) Overexpression of AmpC promotes bacteriophage lysis of ampicillin-resistant Escherichia coli. Frontiers in Microbiology 10: 2973.

17. Wichmann F, Udikovic-Kolic N, Andrew S, Handelsman J (2014) Diverse antibiotic resistance genes in dairy cow manure. mBio 5(2): e01017.

18. Leclercq SO, Wang C, Zhu Y, Wu H, Du X, et al. (2016) Diversity of the tetracycline mobilome within a Chinese pig manure sample. Applied and Environmental Microbiology 82(21): 6454-6462.

19. Stecher B, Denzler R, Maier L, Bernet F, Sanders MJ, et al. (2012) Gut inflammation can boost horizontal gene transfer between pathogenic and commensal Enterobacteriaceae. PNAS 109(4): 1269-1274.

20. He T, Wang Y, Sun L, Maoda Pang M, Zhang L, et al. (2017) Occurrence and characterization of blaNDM-5-positive Klebsiella pneumoniae isolates from dairy cows in Jiangsu, China. Journal of Antimicrobial Chemotherapy 72(1): 90-94

21. Haenni M, Saras E, Châtre P, Meunier D, Martin S, et al. (2009). van A in Enterococcus faecium, Enterococcus faecalis, and Enterococcus casseliflavus detected in French cattle. Foodborne Pathogens and Disease 6(9): 1107-1111.

22. Marinho CM, Santos T, Gonçalves A, Poeta P, Igrejas G (2016) A decade-long commitment to antimicrobial resistance surveillance in Portugal. Frontiers in Microbiology 7: 1650.

23. Krukowski H, Bakuła Z, Iskra M, Olender A, Bis-Wencel H, et al. (2020) The firs outbreak of methicillin-resistant Staphylococcus aureus in dairy cattle in Poland with evidence of on-farm and intrahousehold transmission. Journal of Dairy Science 103(11): 10577-10584.

24. Ceniti C, Britti D, Santoro AML, Musarella R, Ciambrone L, et al. (2017) Phenotypic antimicrobial resistance profile of isolates causing clinical mastitis in dairy animals. Italian Journal of Food Safety 6: 6612.

25. Silva V, Peixoto F, Igrejas G, Parelho C, Garcia P, et al. (2018) First report on vanA-Enterococcus faecalis recovered from soils subjected to long-term livestock agricultural practices in Azores Archipelago. International Journal of Environmental Research 12(1): 39-44.

26. Alduina R (2020) Antibiotics and environment. Antibiotics 9(4): 202.

27. Yoshizawa N, Usui M, Fukuda A, Asai T, Higuchi H, et al. (2020) Manure compost is a potential source of tetracycline-resistant Escherichia coli and tetracycline resistance genes in Japanese farms. Antibiotics 9(2): 76.

28. Fontana C, Favaro M (2018) Chapter 3-Coagulase-positive and coagulasenegative staphylococci in human disease. Pet-To-Man Travelling Staphylococci. A World in Progress pp. 25-42.

29. O'Sullivan JN, Rea MC, O'Connor PM, Hill C, Ross RP (2018) Human skin microbiota is a rich source of bacteriocin-producing staphylococci that kill human pathogens. FEMS Microbiology Ecology 95(2): fiy241.

30. Bai H, He LY, Wu DL, Gao FZ, Zhang M, et al. (2022) Spread of airborne

Citation: : : Pepi M and Focardi S (2021) Antibiotic Resistance in Cattle Livestocks in the Mediterranean Area With A One Health View. Corpus J Vet Dairy Sci 2: 1029 
antibiotic resistance from animal farms to the environment: Dispersal pattern and exposure risk. Environment International 158: 106927.

31. Spiteri CD, Gillis RE, Roffet-Salque M, Castells Navarro L, Guilaine J, et al. (2016) Regional asynchronicity in dairy production and processing in early farming communities of the northern Mediterranean. Proceedings of the National Academy of Sciences (PNAS) 113(48): 13594-13599.

32. Zeder MA (2008) Domestication and early agriculture in the Mediterranean Basin: Origins, diffusion, and impact. Proceedings of the National Academy of Sciences (PNAS) 105(33): 11597-11604

33. Rancourt Mde, Mottet A (2008) Mediterranean animal production: Development or decline? In: Olaizola A, Boutonnet JP, Bernués A (Eds.), Mediterranean livestock production: Uncertainties and opportunities. Zaragoza: CIHEAM/ CITA/CITA, pp.13-22

34. Lika E, Rosić M, Cocoli S, Puvača N, Vuković G, et al. (2021) Antimicrobia resistance of Staphylococcus aureus strains isolated from cow raw milk sample from Albania and Serbia. Mljekarstvo 71(4): 248-256.

35. Belmamoun AR, Reguig KB, Bouazza S, Dif MM (2016) Subclinical mastitis on the raw milk as a risk factor for the transmission of Staphylococcus.aureus and coagulase-negative staphylococci, multidrug resistance in Sidi Bel Abbes, Algeria. Advances in Environmental Biology 10(6).

36. Chorfi K, Bendjemana K, Ayachi A, Mahdi F, Bouzidi NEA (2020) Effect of using treated wastewater on the bacteriological quality of raw cow's milk: A case of a farm in Northeastern Algeria. African Journal of Microbiology Research 14(8): 436-446

37. Tahar S, Nabil MM, Safia T, Ngaiganam EP, Omar A, et al. (2020) Molecular characterization of multidrug-resistant Escherichia coli isolated from milk of dairy cows with clinical mastitis in Algeria. Journal Food Protection 83(12): 2173-2178.

38. Tamendjari S, Bouzebda FA, Chaib L, Aggad H, Ramdani M, et al. (2021) Antibiotic resistance of Staphylococcus aureus isolated from raw cow and goat milk produced in the Tiaret and Souk Ahras areas of Algeria. Veterinary World 14(7):1929-1934

39. Seric Haracic S, Fejzic N, Clanjak Kudra E, Velic S, Smajlovic M (2019) Mastitis in dairy cow farms in canton Sarajevo and antimicrobial resistance of causative agents. IOP Conference Series: Earth and Environmental Science (EES) 333 012099.

40. Leskovec P, Ljoljić DB, Benić M, Kostelić A, Cvetnić Ž, et al. (2015) Sensitivity of selected mastitis pathogens to antimicrobial agents. Mljekarstvo 65(3): 149-158.

41. Abed AH, Menshawy AMS, Zeinhom MMA, Hossain D, Khalifa E, et al. (2021) Subclinical mastitis in selected bovine dairy herds in North Upper Egypt: Assessment of prevalence, causative bacterial pathogens, antimicrobia resistance and virulence-associated genes. Microorganisms 9(6): 1175

42. Ameen F, Reda SA, El-Shatoury SA, Riad EM, Enany ME, et al. (2019) Prevalence of antibiotic resistant mastitis pathogens in dairy cows in Egypt and potential biological control agents produced from plant endophytic actinobacteria. Saud Journal of Biological Sciences 26(7): 1492-1498.

43. Braun SD, Ahmed MFE, El-Adawy H, Hotzel H, Engelmann I, et al. (2016) Surveillance of extended-spectrum beta-lactamase-producing Escherichia coli in dairy cattle farms in the Nile Delta, Egypt. Frontiers in Microbiology 7: 1020.

44. Boireau C, Cazeau G, Jarrige N, Calavas D, Madec JY, et al. (2018) Antimicrobia resistance in bacteria isolated from mastitis in dairy cattle in France, 2006-2016. Journal of Dairy Science 101(10): 9451-9462.

45. Botrel MA, Haenni M, Morignat E, Sulpice P, Madec JY, et al. (2010) Distribution and antimicrobial resistance of clinical and subclinical mastitis pathogens in dairy cows in Rhône-Alpes, France. Foodborne Pathogens and Disease 7(5): 479-487.

46. Bietrix J, Kolenda C, Sapin A, Haenni M, Madec JY, et al. (2019) Persistence and diffusion of mecC-positive CC130 MRSA isolates in dairy farms in Meurthe-etMoselle County (France). Frontiers in Microbiology 10: 47

47. Papadopoulos P, Papadopoulos T, Angelidis A, Kotzamanidis C, Zdragas A, et al. (2020) Staphylococcus aureus and methicilin-resistant Staphylococccus aureus (MRSA) in Greek dairy farms: A "one health" perspective. Ribmins Conference.

48. Filioussis G, Kachrimanidou M, Christodoulopoulos G, Kyritsi M, Hadjichristodoulou C, et al. (2020) Short communication: Bovine mastitis caused by a multidrug-resistant, $m c r-1$-positive (colistin-resistant), extended- spectrum $\beta$-lactamase- producing Escherichia coli clone on a Greek dairy farm. Journal of Dairy Science 103(1): 852-857.

49. Adler A, Sturlesi N, Fallach N, Zilberman-Barzilai D, Hussein O, et al. (2017) Enterobacteriaceae in cattle farms in Israel: Risk factors for carriage and the effect of microbiological methodology on the measured prevalence. Microbial Drug Resistance 23(5): 660-665.

50. Lysnyansky I, Freed M, Rosales RS, Mikula I, Khateb N, et al. (2016) An overview of mycoplasma bovis mastitis in Israel (2004-2014). The Veterinary Journal 207: $180-183$.

51. Laconi A, Mughini-Gras L, Tolosi R, Grilli G, Trocino A, et al. (2021) Microbial community composition and antimicrobial resistance in agricultural soils fertilized with livestock manure from conventional farming in Northern Italy. Science of the Total Environment 760: 143404.

52. Blasi F, Lovito C, Albini E, Bano L, Dalmonte G, et al. (2021) Clostridioides difficile in calves in central italy: prevalence, molecular typing, antimicrobial susceptibility and association with antibiotic administration. Animals 11: 515.

53. Abboud Z, Galuppo L, Tolone M, Vitale M, Puleio R, et al. (2021) Molecular characterization of antimicrobial resistance and virulence genes of bacterial pathogens from bovine and caprine mastitis in Northern Lebanon. Microorganisms 9: 1148 .

54. Zeina K, Pamela AK, Fawwak S (2013) Quantification of antibiotic residues and determination of antimicrobial resistance profiles of microorganisms isolated from bovine milk in Lebanon. Food and Nutrition Sciences 4(7): 1-9.

55. Zouhairi O, Saleh I, Alwan N, Toufeili I, Barbour E, et al. (2010) Antimicrobial resistance of Staphylococcus species isolated from Lebanese dairy-based products. EMHJ 16(12): 1221-1225.

56. Almshawt NF, Hiblu MA, Abid AS, Abbassi MS, Elkady AA, et al. (2020) Antimicrobial resistance among commensal enteric bacteria isolated from healthy cattle in Libya. PAMJ One Health 1(1)

57. Bouymajane A, Filali FR, Oulghazi S, Ed-dra A, Benhallam F, et al. (2018) Occurrence, molecular and antimicrobial resistance of Enterococcus spp. isolated from raw cow's milk trade by street trading in Meknes city, Morocco. GERMS 8(2): 77-84

58. Ramos S, Igrejas G, Rodrigues J, Capelo-Martinez JL, Poeta P (2012) Genetic characterisation of antibiotic resistance and virulence factors in van A-containing enterococci from cattle, sheep and pigs subsequent to the discontinuation of the use of avoparcin. The Veterinary Journal 193(1): 301-303.

59. Amador P, Fernandes R, Prudêncio C, Duarte I (2019) Prevalence of antibiotic resistance genes in multidrug-resistant enterobacteriaceae on portuguese livestock manure. Antibiotics 8(1): 23.

60. López Catalina A, Atxaerandio R, García Rodríguez A, Goiri I, Gutierrez Rivas $\mathrm{M}$, et al. (2021) Characterisation of the rumen resistome in Spanish dairy cattle. Animal Microbiomes 3(1): 63 .

61. García-Galán A, Nouvel LX, Baranowski E, Gómez-Martín Á, Sánchez A, et al (2020) Mycoplasma bovis in spanish cattle herds: Two groups of multiresistant isolates predominate, with one remaining susceptible to fluoroquinolones. Pathogens 9(7): 545.

62. Abbassi MS, Kilani H, Zouari M, Mansouri R, Oussama EF, et al. (2017) Antimicrobial resistance in Escherichia coli isolates from healthy poultry, bovine and ovine in Tunisia: A real animal and human health threat. Journal of Clinical Microbiology and Biochemical Technology 3(1): 019-023.

63. Hassen B, Saloua B, Abbassi MS, Ruiz-Ripa L, Mama OM, et al. (2019) $m c r-1$ encoding colistin resistance in CTX-M-1/CTX-M-15- producing Escherichia coli isolates of bovine and caprine origins in Tunisia. First report of CTX-M15-ST394/D E. coli from goats. Comparative Immunology, Microbiology and Infectious Diseases 67: 101366.

64. Klibi A, Maaroufi A, Torres C, Jouini A (2018) Detection and characterization of methicillin-resistant and susceptible coagulase-negative staphylococci in milk from cows with clinical mastitis in Tunisia. International Journal of Antimicrobial Agents 52(6): 930-935.

65. Ektik N, Gökmen M, Çibik R (2017) The prevalence and antibiotic resistance of methicillin-resistant Staphylococcus aureus (MRSA) in milk and dairy products in balikesir, Turkey. Journal of the Hellenic Veterinary Medical Society 68(4): 613-620.

66. Yapicier ÖS, Sababoglu E, Ozturk D, Turutoglu H, Pehlivanoglu F, et al. (2021)

Citation: : : Pepi M and Focardi S (2021) Antibiotic Resistance in Cattle Livestocks in the Mediterranean Area With A One Health View. Corpus J Vet Dairy Sci 2: 1029 
Lancefield classification and antimicrobial resistance of hemolytic streptococci isolated from bovine mastitis. Veterinaria Italiana 57(1): 41-47.

67. Robinson TP, Bu DP, Carrique-Mas J, Fèvre EM, Gilbert M, et al. (2016) Antibiotic resistance is the quintessential one health issue. Transactions of the
Royal Society of Tropical Medicine and Hygiene 110: 377-380.

68. Dillon ME (2020) The impact of restricting antibiotic use in livestock: Using a 'One Health' approach to analyze effects of the veterinary feed directive. Master's thesis, Harvard Extension School, US. 